\title{
Beta-cell dysfunction in hyperglycaemic rat models: recovery of glucose-induced insulin secretion with lowering of the ambient glucose level
}

\author{
J. L. Leahy and G. C. Weir \\ Research Division, Joslin Diabetes Center, and Departments of Medicine, Brigham and Women's Hospital and \\ New England Deaconess Hospital, Harvard Medical School, Boston, Massachusetts, USA
}

Summary. Glucose-induced insulin secretion is lost in the face of chronic hyperglycaemia. The same defect is present when normal rats are made hyperglycaemic by 48 -h glucose infusions. Insulin secretory responses were mapped out during the post-infusion period in order to determine how long it takes for normal Beta-cell function to recover, and to identify factors which influence the rate of recovery. Male Sprague Dawley rats weighing 200-250 g were infused with $50 \%$ glucose or $77 \mathrm{mmol} / \mathrm{l} \mathrm{NaCl}$ for $48 \mathrm{~h}$. The glucose-infused rats were mildly hypoglycaemic for $14 \mathrm{~h}$ after the infusion ceased. Glucose-induced insulin secretion, absent at the end of the glucose infusion, was normal $6 \mathrm{~h}$ post-infusion. Such rapid recovery was not because of the short duration of hyperglycaemia; mild hypoglycaemia from a 5-h insulin infusion in $90 \%$ pancreatectomized rats resulted in a four-fold rise in glucose-induced insulin secretion. Under in vitro conditions, extreme glucose deprivation caused by perfusing the pan- creas of glucose-infused rats with buffer devoid of glucose restored glucose-induced insulin secretion in just $37 \mathrm{~min}$. Therefore, the suppression of glucose-induced insulin release by chronic hyperglycaemia is a dynamic situation that requires ongoing hyperglycaemia to prevent the reappearance of glucose responsiveness. This study shows recovery of glucose-induced insulin secretion after just $6 \mathrm{~h}$ of mild hypoglycaemia in vivo and even faster recovery with more severe glucose deprivation in vitro. Our results suggest that there is an inverse relationship between the rate of return of Betacell glucose responsiveness and the ambient glucose concentration.

Key words: Animal models, Type 2 (non-insulin-dependent) diabetes mellitus, insulin secretion, insulin treatment, hypoglycaemia, islets of Langerhans.
Normally, the plasma glucose concentration exerts the dominant influence over insulin secretion. Type 2 (noninsulin-dependent) diabetes mellitus is characterized by Beta cells which no longer respond to a changing glucose level [1-4]. We have proposed that glucose-induced insulin secretion is lost as a direct result of Beta cells being exposed to a chronically elevated glucose concentration $[4,5]$. Support for this idea has come from animal studies in which normal rats made hyperglycaemic through a variety of mechanisms develop a similar defect [6-9], and also that normalizing the plasma glucose concentration in these rats with phloridzin restores glucose-induced insulin secretion $[10,11]$.

Little is known about reversal of secretory defects in non-insulin-dependent diabetes mellitus except that restoration of euglycaemia often results in the reappearance of glucose-induced insulin release [4, 12-14]. The recovery time has not been mapped out, nor has much been learned about what conditions speed up or retard re- covery. Animal models should theoretically provide a way to investigate this question, but reversal studies in hyperglycaemic rat models have provided conflicting results. Using in vitro techniques, glucose-induced insulin secretion has been restored in as little as $40 \mathrm{~min}$ [15]. In contrast, in vivo insulin injections have proved to be of varying success and require days to work [16-18]. Part of the discrepancy in these results could reflect the difficulty in attaining precise metabolic control in rats using standard treatments. Alternatively, there may be variables which influence insulin secretion in vivo and are negated by the in vitro techniques.

We have reported that normal rats made hyperglycaemic with 48-h glucose infusions develop Beta-cell glucose unresponsiveness $[8,19]$. With this technique, one has a unique opportunity to study reversal of the secretory defects by simply turning off the infusion. This approach was used in this study to map out recovery of Beta-cell glucose responsiveness. 


\section{Materials and methods}

\section{Chronic glucose infusion rat model}

The glucose infusion method has been described previously [8]. During sodium amobarbital anaesthesia ( $100 \mathrm{mg} / \mathrm{kg}$ i. p.), jugular venous catheters were placed into male Sprague Dawley rats weighing 200 $250 \mathrm{~g}$ (Charles River, Wilmington, Mass., USA). The next day, infusions were started using a Sage syringe pump (Model 355, Orion, Cambridge, Mass., USA) and an infusion device consisting of a swivel with a hollow metal cable running from it to a neck ring and Velcro vest (Emdie, Goochland, Va., USA). The standard protocol was $50 \%$ glucose (weight/volume) or the diluent $77 \mathrm{mmol} / \mathrm{l} \mathrm{NaCl}$ infused at $2 \mathrm{ml} / \mathrm{h}$ for $48 \mathrm{~h}$. Studies were carried out at selected time points after turning off the pump (termination point labelled time 0 ).

\section{$90 \%$ pancreatectomy rat model $(P x)$}

$90 \%$ pancreatectomies were performed on 5-week-old male Sprague Dawley rats using the method of Bonner-Weir et al. [7]. During sodium amobarbital and ether anaesthesia, a midline abdominal incision was made and the pancreas was mobilized by gently breaking mesenteric connections with the stomach, bowel and retroperitoneum. Cotton applicators were used to abrade pancreatic tissue away from the major blood vessels leaving only the portion bordered by the bile duct and the duodenum. Post-operatively, rats were given standard rat chow and tap water ab libitum for 4 to 6 weeks.

\section{In vitro perfused pancreas}

This technique has been described in detail [20]. Prior to anaesthetizing with sodium amobarbital, rats were weighed and blood samples $(0.5 \mathrm{ml})$ were collected by tail snipping for insulin and glucose measurements. Perfusate: Krebs-Ringer bicarbonate buffer $\mathrm{pH} 7.4$ plus $4 \%$ dextran $\mathrm{T}_{70}$ (Sigma, St. Louis, Mich., USA), 0 or $2.8 \mathrm{mmol} / 1 \mathrm{glu}-$ cose, $2 \mathrm{mmol} / / \mathrm{Ca}^{2+}, 1.2 \mathrm{mmol} / 1 \mathrm{Mg}^{2+}$, and $0.2 \%$ bovine serum albumin fraction V (Sigma). After being bubbled for $20 \mathrm{~min}$ with $95 \%$ $\mathrm{O}_{2} / 5 \% \mathrm{CO}_{2}$, the perfusate was stored at $38^{\circ} \mathrm{C}$ in a temperature controlled reservoir; where appropriate, perfusate containing $10 \mathrm{mmol} / \mathrm{l}$ arginine was stored in a second reservoir. Higher glucose concentrations were achieved with a sidearm syringe which added $0.2 \mathrm{ml}$ to the usual flow rate of $3 \mathrm{ml} / \mathrm{min}$. Following cannulation of the aorta and portal vein, the body cavity was covered with gauze soaked in saline and maintained at $36-39^{\circ} \mathrm{C}$ by a heat lamp. The initial $20 \mathrm{~min}$ served as an equilibration period during which no samples were taken. Thereafter, samples were collected in chilled tubes containing $4 \mathrm{mg}$ EDTA and kept on ice pending storage at $-20^{\circ} \mathrm{C}$.

The pancreas was excised at the end of each perfusion, blotted, weighed, and stored in acid ethanol at $-20^{\circ} \mathrm{C}$. Later, on a single day, they were homogenized with an Ultra Turrex (Tekmar, Cincinnati, Ohio, USA), diluted to a volume of $8 \mathrm{ml}$ acid ethanol, and refrozen pending assay for insulin content.

Protocol 1: Glucose-induced insulin secretion after in vitro glucopoenia in glucose-infused rats. Rats were infused with $50 \%$ glucose or $77 \mathrm{mmol} / \mathrm{l} \mathrm{NaCl}$ for $48 \mathrm{~h}$. Glucose-induced insulin secretion was assessed after in vitro perfusion of the pancreas for $37 \mathrm{~min}$ with 0 or $5.5 \mathrm{mmol} / 1$ glucose.

Protocol 2: Beta-cell glucose responsiveness post-glucose infusion. Rats were infused with $50 \%$ glucose or $77 \mathrm{mmol} / \mathrm{NaCl}$ for $48 \mathrm{~h}$. Post-infusion insulin responses were mapped out in vitro using the perfused pancreas technique. Glucose-induced insulin release was assessed at 0 (termination point of the infusion), 4 , and $6 \mathrm{~h}$, and glu- cose potentiation of arginine-induced insulin release at $0,6,14$, and $24 \mathrm{~h}$.

Protocol 3: Beta-cell glucose responsiveness in Px rats post-insulin infusion. At 4 to 6 weeks post $90 \%$ Px rats underwent venous catheterization. The next day, $1 \mathrm{ml} / \mathrm{h}$ infusions were carried out followed by in vitro pancreas perfusion. Infusion protocols: $0.12 \mathrm{IU} / \mathrm{h} \mathrm{Ac}$ trapid insulin (Squibb-Novo, Princeton, NJ, USA) for $5 \mathrm{~h}$, the pancreas was perfused $1 \mathrm{~h}$ later, or $154 \mathrm{mmol} / \mathrm{l} \mathrm{NaCl}+0.25 \%$ bovine serum albumin (diluent) for $6 \mathrm{~h}$. Blood samples $(30 \mu \mathrm{l})$ were obtained hourly for plasma glucose values.

\section{Analytical methods}

Plasma glucose was measured with a Beckman Glucose Analyzer II (Beckman, Brea, Calif., USA). Insulin concentrations were determined by an RIA which used charcoal separation [21] and rat insulin standards (Eli Lilly, Indianapolis, Ind., USA).

\section{Data presentation and statistical analysis}

All data are expressed as mean \pm SEM. Protocols for the perfused pancreas studies are shown at the top of each figure. The incremental insulin responses listed in the tables represent the total amount of insulin released for that secretagogue above the baseline secretory rate; they were calculated by subtracting the last sample taken during the preceding perfusate from the mean insulin concentration during the test perfusate, then multiplying by flow rate and duration. Analysis of variance (ANOVA) was used to determine statistical significance.

\section{Results}

Plasma glucose and insulin values post-infusion (Table 1)

Plasma glucose and insulin values were obtained up to $24 \mathrm{~h}$ after stopping the $\mathrm{NaCl}$ and glucose infusions. As expected, neither value changed in the $\mathrm{NaCl}$ group. Glucose-infused rats were markedly hyperglycaemic and

Table 1. Plasma glucose and insulin values in normal rats following a 48 -h infusion of $50 \%$ glucose or $77 \mathrm{mmol} / 1 \mathrm{NaCl}$

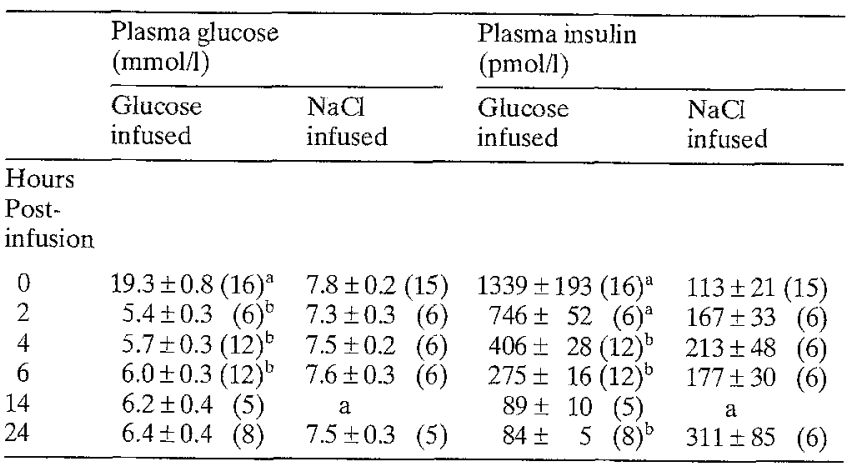

The values in the parentheses are the number of animals in each group.

(a) no samples were taken in $\mathrm{NaCl}$-infused rats $14-\mathrm{h}$ post-infusion. Statistical significance was determined using one-way analysis of variance (ANOVA). Each value in the glucose-infused rats was compared to the corresponding value in the $\mathrm{NaCl}$ group.

${ }^{\mathrm{a}} p<0.001,{ }^{\mathrm{b}} p<0.05$ 
Table 2. Pancreatic weights and insulin contents in normal rats following a 48 -h infusion of $50 \%$ glucose or $77 \mathrm{mmol} / \mathrm{l} \mathrm{NaCl}$

\begin{tabular}{llc}
\hline & $\begin{array}{l}\text { Pancreas weight } \\
(\mathrm{g})\end{array}$ & $\begin{array}{l}\text { Insulin content } \\
\text { (nmol/pancreas) }\end{array}$ \\
\hline 0 h post- $\mathrm{NaCl}(10)$ & $0.74 \pm 0.02$ & $14.3 \pm 1.2$ \\
0 h post-glucose (10) & $0.56 \pm 0.02^{\mathrm{a}}$ & $3.2 \pm 0.3^{\mathrm{a}}$ \\
4 h post-glucose (6) & $0.59 \pm 0.02^{\mathrm{a}}$ & $7.6 \pm 0.3^{\mathrm{a}}$ \\
6 h post-glucose (9) & $0.53 \pm 0.02^{\mathrm{a}}$ & $5.5 \pm 0.5^{\mathrm{a}}$ \\
14 h post-glucose (5) & $0.57 \pm 0.04^{\mathrm{a}}$ & $15.2 \pm 1.1$ \\
24 h post-glucose (5) & $0.65 \pm 0.04^{\mathrm{b}}$ & $12.7 \pm 1.3$ \\
\hline
\end{tabular}

Pancreases were obtained after in vitro perfusion.

The values in parentheses are the number of animals in each group. Statistical significance was determined using one-way analysis of variance (ANOVA). Each glucose-infused group was compared to the corresponding value in the rats infused with $\mathrm{NaCl}$.

${ }^{\mathrm{a}} p<0.001,{ }^{\mathrm{b}} p<0.05$

hyperinsulinaemic. After stopping the infusion, plasma glucose fell precipitously to a level below that of the control rats. Even $24 \mathrm{~h}$ post-infusion, there was a tendency for the glucose value to be reduced $(6.4 \pm 0.4 \mathrm{mmol} / \mathrm{l} \mathrm{glu}$ cose-infused vs $7.5 \pm 0.3 \mathrm{mmol} / 1 \mathrm{NaCl}$-infused, $p<0.07$ ). In spite of the hypoglycaemia, plasma insulin declined slowly taking $14 \mathrm{~h}$ to fall below the level of the control animals.

\section{Pancreatic insulin content post-infusion (Table 2)}

Insulin content was reduced by $75 \%$ at the end of the glucose infusion. It took $14 \mathrm{~h}$ for the content to return to normal.

Protocol 1: Glucose-induced insulin secretion after in vitro glucopoenia in glucose-infused rats (Fig.1). Rats were studied directly after a 48 -h infusion of $50 \%$ glucose or $77 \mathrm{mmol} / \mathrm{l} \mathrm{NaCl}$. The baseline perfusate contained $16.7 \mathrm{mmol} / 1 \mathrm{glucose}$ followed either by 0 or $5.5 \mathrm{mmol} / \mathrm{glu}-$ cose for $37 \mathrm{~min}$, and then a re-challenge with $16.7 \mathrm{mmol} / 1$ glucose.

The results in the $\mathrm{NaCl}$-infused groups were essentially the same; the insulin responses to the high glucose challenge were very similar whether the preceding perfusate contained 0 or $5.5 \mathrm{mmol} / 1$ glucose. In the glucose-infused rats, both low glucose perfusates paradoxically raised the insulin concentration. Continued delivery of $5.5 \mathrm{mmol} / 1$ glucose caused insulin output to return to the baseline level followed by an incremental insulin response to the high glucose challenge which was less than that of the control groups. In contrast, the glucose-free perfusate reduced insulin output to the negligible levels seen in the controls, and the insulin response to high glucose was five times that of the previous group, even surpassing that of the control group.

Protocol 2: Beta-cell glucose responsiveness post-glucose infusion. Insulin secretion post-infusion was mapped out with the in vitro perfused pancreas. Glucose-induced insulin release was assessed with the following protocol: $16.7 \mathrm{mmol} / 1$ glucose followed in turn by $2.8 \mathrm{mmol} / 1$ for $10 \mathrm{~min}$ and $16.7 \mathrm{mmol} / 1$ for $15 \mathrm{~min}$ (Fig. 2). Pancreas from the NaCl-infused controls behaved as expected with suppression of insulin output during low glucose followed by a large biphasic response to high glucose. The results at the end of the glucose infusion were entirely different; insulin release paradoxically increased during exposure to the low glucose concentration while changing to high glucose had virtually no effect on insulin output. Four h later, the pattern of insulin output was more normal looking, with the paradoxical rise to low glucose having almost disappeared and high glucose now causing a definite biphasic response. However, the size of that response was only a fourth of the control value (Table 3 ). Six $h$ after stopping the infusion, suppression and stimulation of insulin release were both essentially normal.

Next, glucose potentiation of arginine-induced insulin secretion was assessed by giving 5-min infusions of
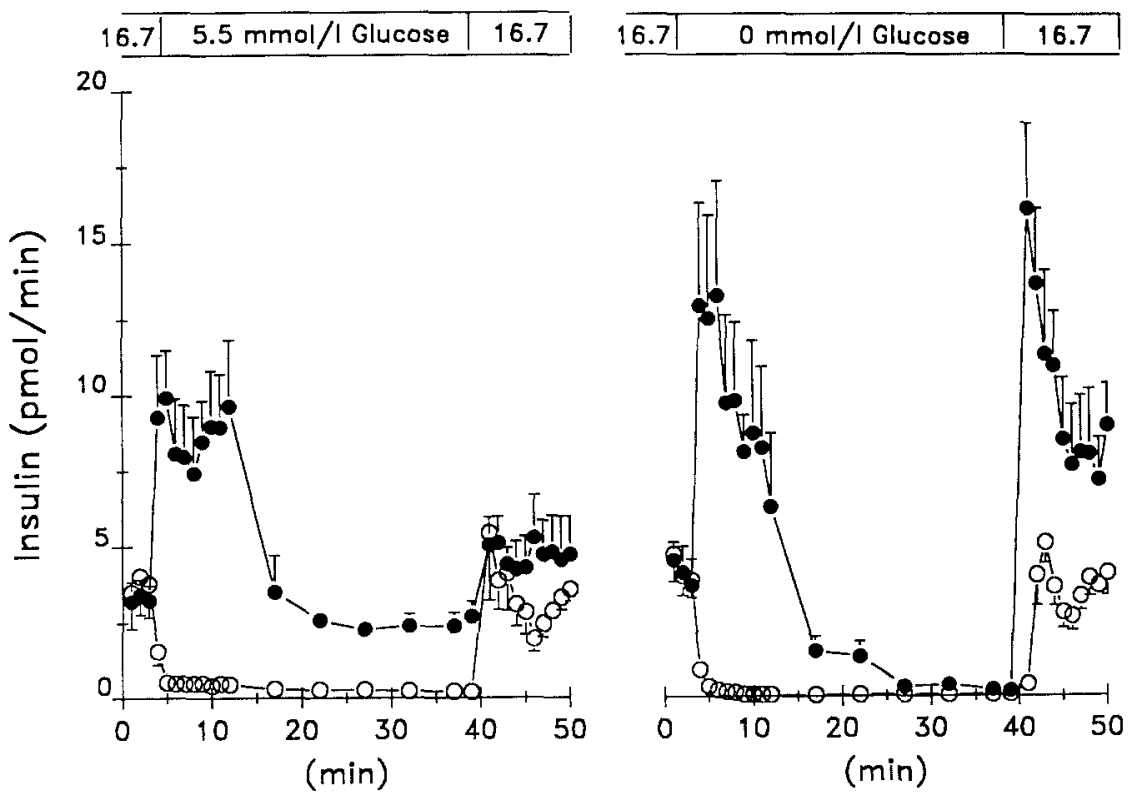

Fig. 1. Effect of in vitro glucopoenia on glucose-induced insulin secretion in normal rats infused for $48 \mathrm{~h}$ with $50 \%$ glucose (-) or $77 \mathrm{mmol} / 1 \mathrm{NaCl}(\mathrm{O}-\mathrm{O})$. Insulin secretion was assessed in vitro with the perfused pancreas technique. Perfusion protocol: $10 \mathrm{~min}$ infusion of $16.7 \mathrm{mmol} / 1$ glucose preceded by $37 \mathrm{~min}$ of 0 or $5.5 \mathrm{mmol} / \mathrm{l}$ glucose. Each group consisted of five or six animals 


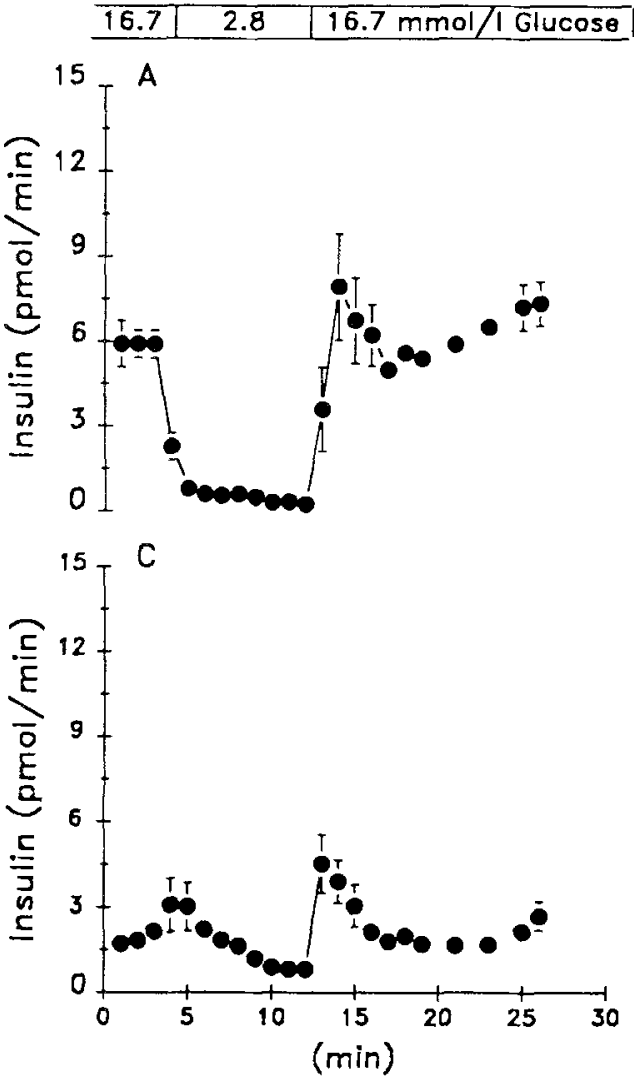

\begin{tabular}{l|l|l|l|}
\hline 6.7 & 2.8 & $16.7 \mathrm{mmol} / 1$ Glucose \\
\hline
\end{tabular}

B

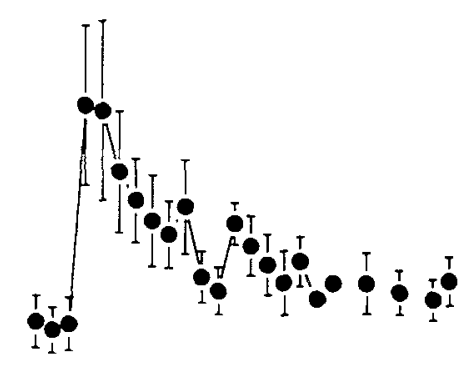

D

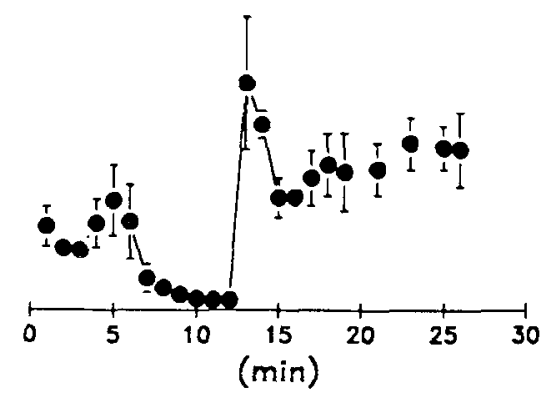

Fig. 2 A-D. Glucose-induced insulin secretion in normal rats following a 48 -h infusion of $50 \%$ glucose or $77 \mathrm{mmol} / \mathrm{l} \mathrm{NaCl}$. Insulin secretion was assessed in vitro with the perfused pancreas technique. Perfusion protocol: $16.7 \mathrm{mmol} / 1$ glucose followed in turn by $2.8 \mathrm{mmol} / 1$ for $10 \mathrm{~min}$ and $16.7 \mathrm{mmol} / \mathrm{l}$ for $15 \mathrm{~min}$. Glucoseinfused rats were studied at the end of the infusion $(\mathbf{B}), 4(\mathbf{C})$ or $6 \mathrm{~h}(\mathbf{D})$ later. $\mathrm{NaCl}$-infused rats were studied at the end of the infusion (A). Each group consisted of five or six animals
Table 3. Glucose-induced insulin secretion in normal rats after a 48 -h infusion of $50 \%$ glucose or $77 \mathrm{mmol} / \mathrm{h} \mathrm{NaCl}$ assessed with the in vitro perfused pancreas

\begin{tabular}{lll}
\hline & Insulin release \\
\cline { 2 - 3 } & $\begin{array}{l}2.8 \mathrm{mmol} / \mathrm{l} \text { glucose } \\
(\mathrm{pmol} / \mathrm{min})\end{array}$ & $\begin{array}{l}\text { Incremental re- } \\
\text { sponse to } \\
16.7 \mathrm{mmol} / \mathrm{l} \text { glucose } \\
(\mathrm{pmol} / 15 \mathrm{~min})\end{array}$ \\
\hline 0 h post- $\mathrm{NaCl}(5)$ & $0.25 \pm 0.18$ & $88.6 \pm 7.12$ \\
0 h post-glucose (5) & $4.07 \pm 0.84^{\mathrm{c}}$ & $7.56 \pm 9.79^{\mathrm{b}}$ \\
4h post-glucose (6) & $0.83 \pm 0.15^{\mathrm{c}}$ & $22.4 \pm 4.88^{\mathrm{b}}$ \\
6 h post-glucose (5) & $0.36 \pm 0.21$ & $75.5 \pm 11.2$ \\
\hline
\end{tabular}

The values in parentheses are the number of animals in each group. a The value at $2.8 \mathrm{mmol} / \mathrm{l}$ glucose is the amount of insulin released during the last min of that perfusate.

Statistical significance was determined using one-way analysis of variance (ANOVA). Each glucose-infused group was compared to the corresponding value in the rats infused with $\mathrm{NaCl}$.

${ }^{b} p<0.001,{ }^{c} p<0.05$

$10 \mathrm{mmol} / \mathrm{l}$ arginine at 2.8 and $16.7 \mathrm{mmol} / \mathrm{l}$ glucose (Fig. 3). Glucose potentiation was clearly evident in the NaCl-infused rats; the arginine response at low glucose was trivial compared to that at high glucose concentration. In contrast, at the end of the glucose infusion, the glucose concentration had no effect on arginine-induced insulin release; both insulin responses were large (exceeding that of the control animals at $16.7 \mathrm{mmol} / \mathrm{l}$ glucose) and nearly identical. Contrary to the previous protocol in which glucose-induced insulin release normalized within $6 \mathrm{~h}$ of turn- ing off the infusion, the arginine response at low glucose was still well above normal (Table 4) so that the study was extended to 14 and then $24 \mathrm{~h}$ post-infusion. At $14 \mathrm{~h}$, the response to arginine at low glucose was still 10 times that of the control animals. Unexpectedly, at $24 \mathrm{~h}$ the arginine responses at both glucose concentrations were higher than at $14 \mathrm{~h}$ and were clearly above those of the control rats.

Protocol 3: Beta-cell glucose responsiveness in Px rats post-insulin infusion. Glucose-induced insulin secretion was normal $6 \mathrm{~h}$ after stopping the glucose infusion. However, this model is characterized by a short duration $(48 \mathrm{~h})$ of hyperglycaemia, and it was not clear if as rapid return of glucose responsiveness would be possible had the duration of hyperglycaemia been longer. To answer this question, $90 \%$ Px rats were infused with insulin to mimic the experimental conditions that followed termination of the glucose infusion. Px rats develop a 1-2 mmol/l rise in plasma glucose within a week of the surgery [7]; they were studied 4-6 weeks after the Px surgery so that the duration of hyperglycaemia was at least 3 weeks.

In the insulin-infused Px rats, plasma glucose fell within $2 \mathrm{~h}$, from $8.5 \pm 0.4 \mathrm{mmol} / \mathrm{l}$ to $3.9 \pm 0.1 \mathrm{mmol} / \mathrm{l}$ (Fig. 4 ). The perfusion surgery was started $1 \mathrm{~h}$ after stopping the infusion at a time when the glucose value had returned to $8.7 \pm 0.7 \mathrm{mmol} / 1$. Perfusion protocol: $7.8 \mathrm{mmol} / 1$ glucose followed in turn by $2.8 \mathrm{mmol} / 1$ glucose $\times 10 \mathrm{~min}$, $16.7 \mathrm{mmol} / \mathrm{l}$ glucose $\times 15 \mathrm{~min}$, and $16.7 \mathrm{mmol} / \mathrm{l}$ glucose $+10 \mathrm{mmol} / \mathrm{l}$ arginine $\times 8 \mathrm{~min}$ (Fig.5). The $\mathrm{NaCl}$-infused Px rats showed the typical pattern of selective glucose unresponsiveness with high glucose causing a meager 

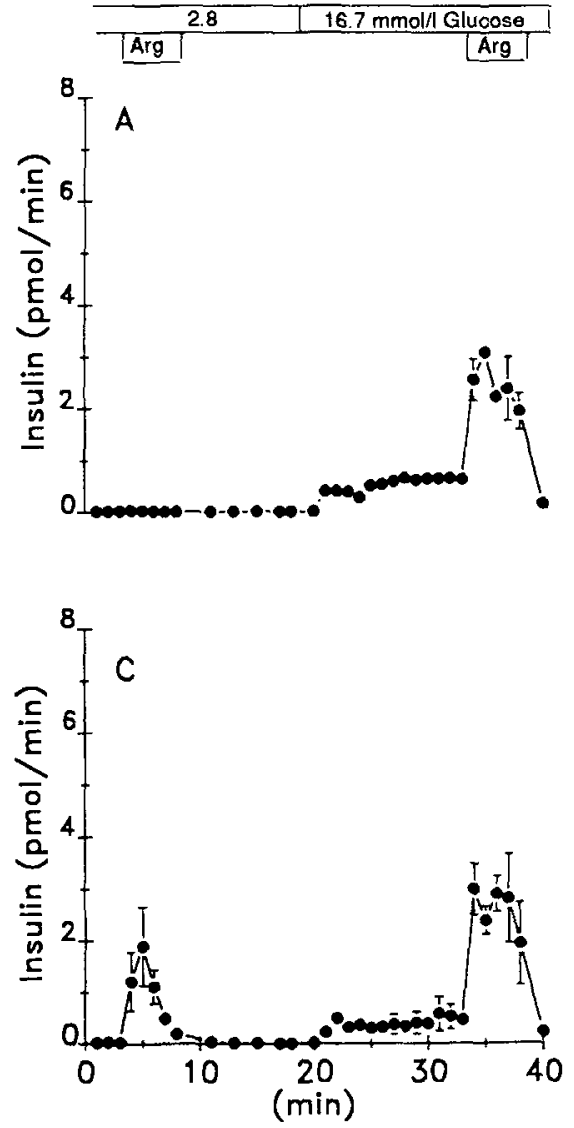

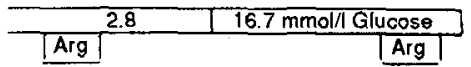

B

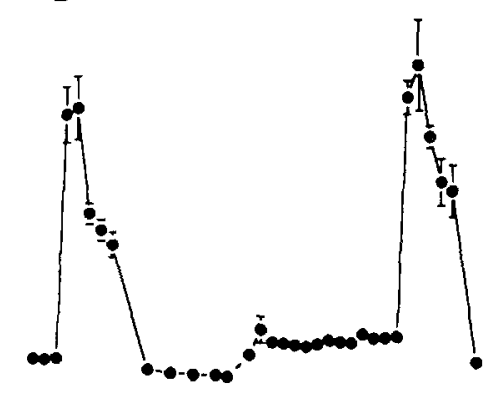

D

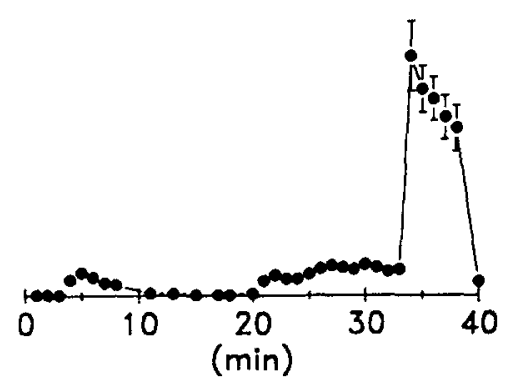

Fig. 3 A-D. Glucose potentiation of arginine-induced insulin secretion in normal rats following a $48-\mathrm{h}$ infusion of $50 \%$ glucose or

$77 \mathrm{mmol} / 1 \mathrm{NaCl}$. Insulin secretion was assessed in vitro with the perfused pancreas technique. Perfusion protocol: 5 -min infusions of $10 \mathrm{mmol} / \mathrm{l}$ arginine given at 2.8 and $16.7 \mathrm{mmol} / \mathrm{l}$ glucose. Glucose-infused rats were studied at the end of the infusion (B), 6 (C) or $24 \mathrm{~h}$ (D) later. $\mathrm{NaCl}$-infused rats were studied 24 h post-infusion $(\mathbf{A})$. Each group consisted of four or five animals
Table 4. Glucose influence over arginine-induced insulin secretion in normal rats after a $48-\mathrm{h}$ infusion of $50 \%$ glucose or $77 \mathrm{mmol} / \mathrm{l}$ $\mathrm{NaCl}$ assessed with the in vitro perfused pancreas

\begin{tabular}{|c|c|c|}
\hline & \multicolumn{2}{|l|}{ Insulin release } \\
\hline & $\begin{array}{l}\text { Incremental response } \\
2.8 \mathrm{mmol} / \mathrm{l} \text { glucose }+ \\
10 \mathrm{mmol} / / \text { arginine } \\
(\mathrm{pmol} / 5 \mathrm{~min})\end{array}$ & $\begin{array}{l}\text { Incremental response } \\
16.7 \mathrm{mmol} / \mathrm{l} \text { glucose }+ \\
10 \mathrm{mmol} / \mathrm{l} \text { arginine } \\
(\mathrm{pmol} / \mathrm{min})\end{array}$ \\
\hline $24 \mathrm{~h}$ post $-\mathrm{NaCl}(5)$ & $0.61 \pm 0.30$ & $90.0 \pm 8.30$ \\
\hline 0 h post-glucose (5) & $170 \pm 12.0^{\mathrm{a}}$ & $196 \pm 24.1^{b}$ \\
\hline $6 \mathrm{~h}$ post-glucose (4) & $48.2 \pm 17.2^{b}$ & $107 \pm 21.9$ \\
\hline $14 \mathrm{~h}$ post-glucose (5) & $6.55 \pm 1.41^{b}$ & $93.1 \pm 31.1$ \\
\hline $24 \mathrm{~h}$ post-glucose (5) & $15.1 \pm 3.00^{\mathrm{b}}$ & $166 \pm 14.4^{\mathrm{b}}$ \\
\hline
\end{tabular}

The values in parentheses are the number of animals in each group. Statistical significance was determined using one-way analysis of variance (ANOVA). Each glucose-infused group was compared to the corresponding value in the rats infused with $\mathrm{NaCl}$.

${ }^{\mathrm{a}} p<0.001,{ }^{\mathrm{b}} p<0.05$

insulin response as compared to arginine (note the scale change on Fig.5). After the insulin infusion, the insulin response to $16.7 \mathrm{mmol} / 1$ glucose increased four-fold $(17.6 \pm 3.53 \mathrm{pmol} / 15 \mathrm{~min} \quad \mathrm{Px}$-insulin vs $4.75 \pm 1.00$ $\mathrm{pmol} / 15 \mathrm{~min} \mathrm{Px}-\mathrm{NaCl}, p<0.02$ ) and that to arginine doubled $(82.7 \pm 14.5 \mathrm{pmol} / 8 \mathrm{~min}$ Px-insulin vs $44.7 \pm$ $4.36 \mathrm{pmol} / 8 \mathrm{~min} \mathrm{Px}-\mathrm{NaCl}, p<0.06)$. These improvements were not accompanied by any change in pancreatic insulin content $(3.6 \pm 0.6 \mathrm{nmol} /$ pancreas Px-insulin vs $4.0 \pm$ $0.5 \mathrm{nmol} /$ pancreas $\mathrm{Px}-\mathrm{NaCl})$.

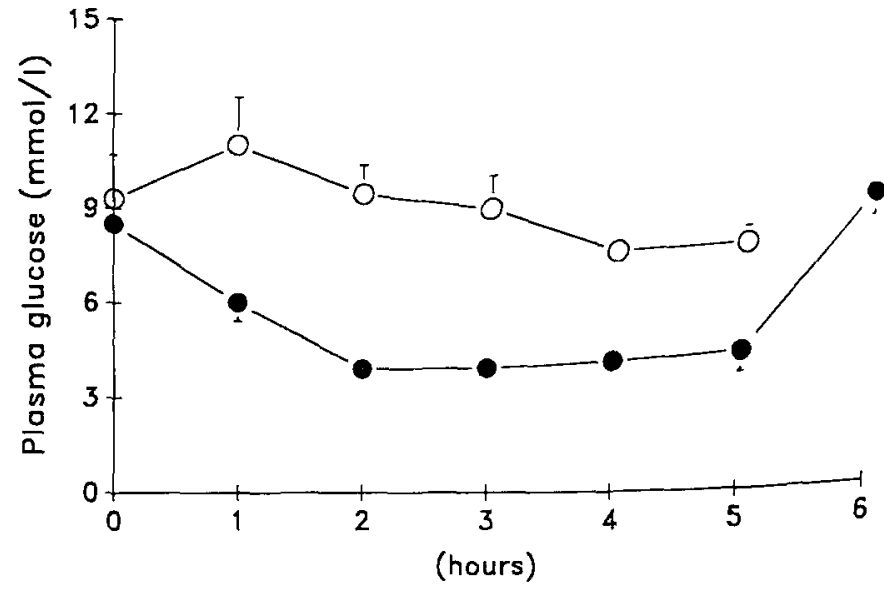

Fig.4. Plasma glucose values during a 5-h infusion of $0.12 \mathrm{IU} / \mathrm{h}$ Actrapid insulin (-) or a 6-h infusion of $154 \mathrm{mmol} / \mathrm{l} \mathrm{NaCl}(\mathrm{O}-\mathrm{O})$ in rats $4-6$ weeks after a $90 \%$ pancreatectomy. The sample at $6 \mathrm{~h}$ in the insulin-infused rats was collected $1 \mathrm{~h}$ post-infusion

\section{Discussion}

The glucose-infused rats were characterized by near total loss of glucose influence over insulin secretion; direct stimulation of insulin secretion and glucose modulation of arginine-induced insulin output (referred to as glucose potentiation) were both absent. Perfusing the pancreas of these rats in vitro for just $37 \mathrm{~min}$ with glucose-free buffer restored glucose-induced insulin secretion such that the insulin response to a glucose challenge now exceeded that 


\begin{tabular}{|l|l|l|}
\hline 7.8 & 2.8 & $16.7 \mathrm{mmol} / \mathrm{I}$ Glucose \\
\hline
\end{tabular}

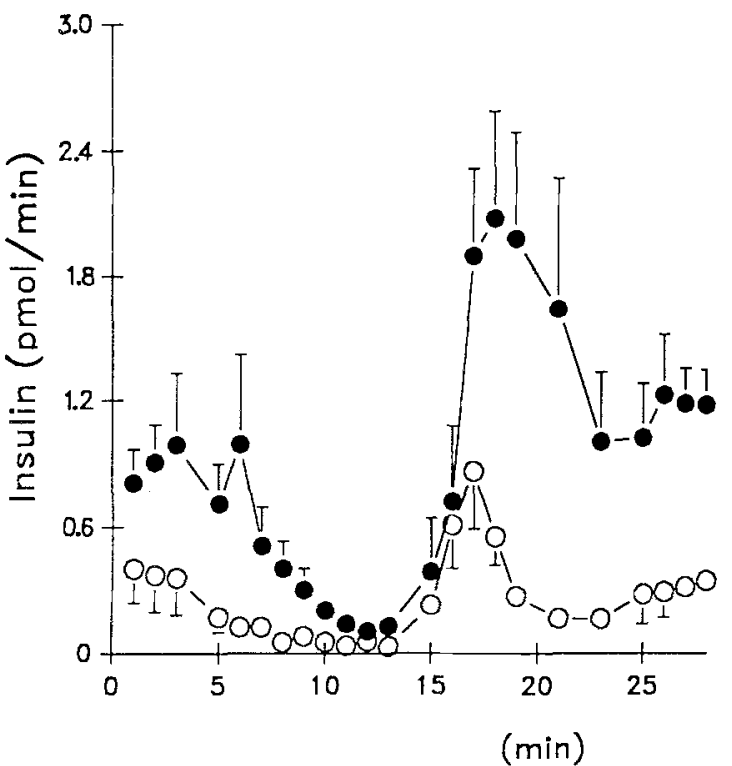

of the NaCl-infused control rats. In contrast, perfusate containing $5.5 \mathrm{mmol} / \mathrm{l}$ glucose (well below the normal plasma glucose value in rats) failed to achieve the same effect, indicating that the return of glucose-induced insulin secretion was not simply an effect of removing hyperglycaemia but instead depended on the absence (or possibly extremely low level) of glucose. The same observation has been made in other hyperglycaemic rodent models $[15,22$, $23]$ suggesting that rapid restoration of glucose responsiveness in the presence of profound glucopoenia is a fundamental characteristic of hyperglycaemia-associated Beta-cell dysfunction.

Some aspects of these findings need to be emphasized. First, glucose-induced insulin secretion normalized in just 37 min which is important from a mechanistic point of view, for it tells us that the biochemical changes in the Beta-cell that lead to recovery of glucose-induced insulin secretion are not dependent on protein synthesis. A current hypothesis is that glucose-induced insulin secretion is lost secondary to a reduced level of the high $\mathrm{K}_{\mathrm{m}}$ Beta-cell glucose transporter [24]. This possibility is not easily reconciled with the rapid reversibility of the secretory defect as shown in this study. More consistent with our findings is the hypothesis that excess accumulation of glycogen within the Beta-cell is responsible for the secretory defects [25, 26]. It was demonstrated more than 20 years ago that the glycogen stores in Beta cells of hyperglycaemic rats are mobilized within 45 min of being exposed in vitro to a very low glucose concentration [27]. Second, the rapid reversability may explain the paradox whereby perfused pancreas studies in diabetic rat models have routinely shown loss of glucose-induced insulin output [28] whereas isolated islets from these same rats are normally glucose responsive [29-31]. The most likely explanation is that during the several hour isolation procedure Beta cells are no longer exposed to the same high glucose levels which occur in vivo, thereby allowing glucose-induced insulin secretion to revert to normal. Support for this idea has come

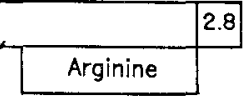

Fig. 5. Rats 4-6 weeks after a $90 \%$ pancreatectomy were infused with $0.12 \mathrm{IU} / \mathrm{h}$ Actrapid insulin for $5 \mathrm{~h}$ ( or $154 \mathrm{mmol} / 1 \mathrm{NaCl}$ for $6 \mathrm{~h}(\mathrm{O}-\mathrm{O})$. Insulin secretion was then assessed in vitro with the perfused pancreas technique. Perfusion protocol: $7.8 \mathrm{mmol} / \mathrm{lglucose}$ followed in turn by $2.8 \mathrm{mmol} / \mathrm{l}$ glucose for $10 \mathrm{~min}$, $16.7 \mathrm{mmol} / 1$ glucose for $15 \mathrm{~min}$, and $16.7 \mathrm{mmol} / \mathrm{l}$ glucose $+10 \mathrm{mmol} / \mathrm{l}$ arginine for $8 \mathrm{~min}$. Note the $\mathrm{Y}$ axis scale change at $30 \mathrm{~min}$. Each group represents four or five animals

from recent studies which have shown partial preservation of secretory defects in islets from glucose-infused normal rats when the solutions used in the isolation procedure contain higher than normal glucose concentrations $[32,33]$.

It has been considerably more difficult to study reversal of insulin secretory defects under in vivo conditions, in part because of problems in attaining precise metabolic control in rats using insulin injections. We took the approach of mapping out insulin secretion patterns in glucose-infused normal rats during the post-infusion period. Glucose-induced insulin secretion was normal $6 \mathrm{~h}$ after turning off the infusion. The glucose infusion method entails relatively short-term hyperglycaemia, and it was not clear if the reversal would have been as fast if the exposure to hyperglycaemia had been longer. This question was answered by showing that a 6 -h insulin infusion caused a four-times higher insulin response to an in vitro glucose challenge in the Px model which is characterized by several weeks of hyperglycaemia. Thus, even after a protracted period of hyperglycaemia, mild hypoglycaemia allows Beta-cell glucose responsiveness to reappear within a few hours. These results contradict a previous study which suggested that recovery of glucoseinduced insulin secretion in vivo requires several days of insulin treatment [18]. On the other hand, we cannot exclude the possibility that a counter-regulatory rise in glucagon release accelerated the return of glucose-induced insulin secretion.

In contrast to glucose-induced insulin secretion normalizing within $6 \mathrm{~h}$ of stopping the glucose infusion, glucose influence over arginine-induced insulin release was still abnormal $24 \mathrm{~h}$ post-infusion. This latter result was somewhat surprising since $24 \mathrm{~h}$ of insulin therapy fully reverses the same defect in neonatal streptozotocin rats $[16,18]$; the longer duration in this study may reflect the greater degree of hyperglycaemia in the glucose-infused model. Regardless of this, the striking finding is the dis- 
parity in the timing of recovery of glucose-induced insulin secretion vs glucose potentiation. The time which it takes for these two defects to develop in glucose-infused rats is also quite different [19]. The most plausible explanation for these observations is that the loss of glucose-induced insulin secretion and the loss of glucose potentiation result from separate molecular abnormalities.

Our results clearly show that suppression of glucose-induced insulin release by chronic hyperglycaemia is a dynamic situation that requires ongoing hyperglycaemia to prevent reappearance of glucose responsiveness. The in vitro results showed that a very low glucose concentration accelerates the recovery of normal Beta-cell function. However, it should not be inferred that the same principle applies in vivo. Any benefits of marked hypoglycaemia to promote a return of glucose responsiveness would have to compete with associated factors which inhibit insulin secretion such as hyperinsulinaemia [34] and increases in circulating catecholamines $[35,36]$. Hypoglycaemia-induced suppression of insulin secretion presumably explains our unexpected finding that arginine-induced insulin release at $16.7 \mathrm{mmol} / \mathrm{l}$ glucose fell after turning off the glucose infusion but then rose again $24 \mathrm{~h}$ later.

In summary, the in vitro approach allows study of hyperglycaemia-induced Beta-cell dysfunction in an environment in which the ambient glucose level is the only factor known to influence the rate of recovery of Beta-cell glucose responsiveness. These results suggest that the lower the glucose level, the faster is recovery. In contrast, the in vivo state is much more complex with additional factors related to hypoglycaemia being able to suppress insulin secretion and thereby counter-balance any beneficial effects. These results have important implications for the therapy of Type 2 diabetes for which a desireable therapeutic endpoint is to optimize endogenous Beta-cell function. To attain this goal, treatment strategies must successfully maintain the delicate balance between sufficient lowering of glucose values to negate any effects of hyperglycaemia while avoiding hypoglycaemia. Unfortunately, the current approaches for close metabolic control using insulin are frequently accompanied by hypoglycaemia [37] which might argue for the development of new innovative management programmes based on the aggressive use of diet, weight reduction, and oral agents.

Acknowledgements. This work was supported by Grants DK-38543, DK-35449, and DK-36836 (Diabetes Endocrinology Research Center Animal Research Core) from the National Institutes of Health.

\section{References}

1. Seltzer HS, Allen EW, Herron AL Jr, Brennan MT (1967) Insulin secretion in response to glycemic stimulus: relation of delayed initial release to carbohydrate intolerance in mild diabetes mellitus. J Clin Invest 46: 323-335

2. Perley MJ, Kipnis DM (1967) Plasma insulin responses to oral and intravenous glucose: studies in normal and diabetic subjects. J Clin Invest 46: 1954-1962

3. Cerasi E, Luft R (1967) The plasma insulin response to glucose infusion in healthy subjects and in diabetes mellitus. Acta Endocrinol 55:278-304
4. Leahy JL (1990) Natural history of B-cell dysfunction in NIDDM. Diabetes Care 13: 992-1010

5. Weir GC (1982) Non-insulin-dependent diabetes mellitus: interplay between B-cell inadequacy and insulin resistance. Am J Med 73: 461-464

6. Weir GC, Clore ET, Zmachinski CJ, Bonner-Weir S (1981) Islet secretion in a new experimental model for non-insulin-dependent diabetes. Diabetes 30:590-595

7. Bonner-Weir S, Trent DF, Weir GC (1983) Partial pancreatectomy in the rat and subsequent defect in glucose-induced insulin release. J Clin Invest 71: 1544-1553

8. Leahy JL, Cooper HE, Deal DA, Weir GC (1986) Chronic hyperglycemia is associated with impaired glucose influence on insulin secretion: a study in normal rats using chronic in vivo glucose infusions. I Clin Invest 77: 908-915

9. Leahy JL, Bonner-Weir S, Weir GC (1988) Minimal chronic hyperglycemia is a critical determinant of impaired insulin secretion after an incomplete pancreatectomy. J Clin Invest 81: 14071414

10. Rossetti L, Shulman GI, Zawalich W, DeFronzo RA (1987) Effect of chronic hyperglycemia on in vivo insulin secretion in partially pancreatectomized rats. J Clin Invest 80: 1037-1044

11. Leahy JL, Cooper HE, Weir GC (1987) Impaired insulin secretion associated with near normoglycemia: study in normal rats with 96-h in vivo glucose infusions. Diabetes 36: 459-464

12. Kosaka K, Kuzuya T, Akanuma Y, Hagura R (1980) Increase in insulin response after treatment of overt maturity-onset diabetes is independent of the mode of treatment. Diabetologia 18:23-28

13. Vague P, Moulin J-P (1982) The defective glucose sensitivity of the $B$-cell in noninsulin dependent diabetes: improvement after twenty hours of normoglycemia. Metabolism 31: 139-142

14. Glaser B, Leibovich G, Nesher R, Hartling S, Binder C, Cerasi E (1988) Improved beta-cell function after intensive insulin treatment in severe non-insulin-dependent diabetes. Acta Endocrinol 118: 365-373

15. Grill V, Westberg M, Östenson C-G (1987) B cell insensitivity in a rat model of non-insulin-dependent diabetes: evidence for a rapidly reversible effect of previous hyperglycemia. J Clin Invest 80: 664-669

16. Leahy JL, Bonner-Weir S, Weir GC(1985) Abnormal insulin secretion in a steptozocin model of diabetes. Effects of insulin treatment. Diabetes 34: 660-666

17. Grill V, Rundfeldt M (1986) Abnormalities of insulin responses after previous exposure to glucose in streptozocin-diabetic and dexamethasone-treated rats. Role of hyperglycemia and increased B-cell demands. Diabetes 35: 44-51

18. Kergoat M, Bailbe D, Portha B (1987) Insulin treatment improves glucose-induced insulin release in rats with NIDDM induced by streptozocin. Diabetes 36: 971-977

19. Leahy JL, Weir GC (1988) Evolution of abnormal insulin responses during 48-h in vivo hyperglycemia. Diabetes 37: 217-222

20. Weir GC, Knowlton SD, Martin DB (1974) Glucagon secretion from the perfused rat pancreas: studies with glucose and catecholamines. J Clin Invest 54: 1403-1412

21. Albano JDM, Ekins RP, Maritz G, Turner RC (1972) A sensitive, precise radioimmunoassay of serum insulin relying on charcoal separation of bound and free hormone moieties. Acta Endocrinol 70: 487-509

22. Voyles NR, Powell AM, Timmers KI et al. (1988) Reversible impairment of glucose-induced insulin secretion in SHR/N-cp rats. Diabetes 37: 398-404

23. Portha B, Serradas P, Bailbé B, Suzuki K-I, Goto Y, Giroix M-H (1991) B-cell insensitivity to glucose in the GK rat, a spontaneous nonobese model for type II diabetes. Diabetes 40:486-491

24. Unger RH (1991) Diabetic hyperglycemia: link to impaired glucose transport in pancreatic B cells. Science 251: 1200-1205

25. Marynissen G, Leclercq-Meyer V, Sener A, Malaisse WJ (1990) Pertubation of pancreatic islet function in glucose-infused rats. Metabolism 39: 87-95

26. Grill V, Ostenson C-G (1988) The influence of a diabetic state on insulin secretion: studies in animal models of non-insulin de- 
pendent diabetes. In: Grill V, Efendić S (eds) Pathogenesis of non-insulin dependent diabetes mellitus. Raven, New York, pp 93-106

27. Hellman B, Idahl L- $\AA$ (1969) Presence and mobilization of glycogen in mammalian pancreatic $\beta$ cells. Endocrinology $84: 1-8$

28. Weir GC, Leahy JL, Bonner-Weir S (1986) Experimental reduction of B-cell mass: implications for the pathogenesis of diabetes. Diab Metab Rev 2: 125-161

29. Halban PA, Bonner-Weir S, Weir GC (1983) Elevated proinsulin biosynthesis in vitro from a rat model of non-insulin-dependent diabetes mellitus. Diabetes 32: 277-283

30. Portha B (1985) Decreased glicose-induced insulin release and biosynthesis by islets of rats with non-insulin-dependent diabetes mellitus: effects of tissue culture. Endocrinology 117: 1735-1741

31. Portha B, Giroix M-H, Serradas P et al. (1988) Insulin production and glucose metabolism in isolated pancreatic islets of rats with NIDDM. Diabetes 37: 1226-1233

32. Timmers KI, Powell AM, Voyles NR et al. (1990) Multiple alterations in insulin responses to glucose in islets from 48 -h glucoseinfused nondiabetic rats. Diabetes 39: 1436-1444

33. Bedoya FJ, Jeanrenaud B (1991) Evolution of insulin secretory response to glucose by perifused islets from lean (FA/FA) rats chronically infused with glucose. Diabetes 40:7-14
34. Argoud GM, Schade DS, Eaton RP (1987) Insulin suppresses its own secretion in vivo. Diabetes 36: $959-962$

35. Samols E, Weir GC (1979) Adrenergic modulation of pancreatic $A, B$, and D cells. $\alpha$-adrenergic stimulation of glucagon secretion in the perfused dog pancreas. J Clin Invest 63:230-238

36. Itoh M, Gerich JE (1982) Adrenergic modulation of pancreatic somatostatin, insulin, and glucagon secretion: evidence for differential sensitivity of islet A, B, and D cells. Metabolism 31: 715-720

37. The DCCT Research Group (1987) Diabetes control and complications trial: results of feasability study. Diab Care 10:1-19

Received: 18 March 1991

and in revised form: 11 June 1991

Dr. J.L.Leahy

Joslin Diabetes Center

1 Joslin Place

Boston, Mass, 02215

USA 